\title{
Hallyu Wave Syndrome: Does Country of Origin Matter?
}

\author{
V. Gaffar, C. A. K.Gautama \\ Management Study Program \\ Universitas Pendidikan Indonesia \\ vanessa@upi.edu
}

\begin{abstract}
Hallyu wave or Korean wave is becoming a world hit, recently. It is a terminology that describes the spread of Korean culture globally. This research is mainly discussed about country of origin perceived by consumer of Korean cosmetic product and it's influenced on purchase decision. The purpose of this research is to describe country of origin and purchase decision as well as to analyze the influence of country of origin on purchase decision. Sample of this research is 261 youngsters who already bought Korean cosmetics product, using purposive sampling technique. Multiple regression method was used to analyze the data. Result shows that majority of youngster perceived South Korea as an ideal place to be visited. Most consumers bought the product mainly because of its function. There is a positive influence between country of origin and purchase decision of Korean Cosmetics Product. Country with good image will motivate consumer to buy its product.
\end{abstract} wave

Keywords: country of origin, purchase decision, hallyu

\section{INTRODUCTION}

Hallyu wave or Korean wave is becoming more popular, globally. It began with the success of K-Pop in China, Hongkong, Thailand, Indonesia, The Phillipines, United States, Latin America and Middle East. The influence of Hallyu Wave attracts world society to know more about Korean Culture, especially south Korean. The phenomenon of Hallyu wave not only benefit South Korean music industry, but also other industries such as electronic industry, cosmetics, television show, film industry, fashion and culinary. A lot of people want to use Korean cosmetics product because they want to look beautiful like Korean stars. This is an opportunity for Korean cosmetic industry to expand their market in Indonesia. Nowadays, there are many Korean cosmetics brand enter Indonesian market, such as Etude, It's Skin, Face Shop, Nature Republic, Tony Moly and Lageine.

This research explores the effect of Hallyu wave from country of origin perspective and its influence on purchase decision. Previous research studied the influence of country of origin and its effect on purchase intention while this research explores more on purchase decision, which is the actual purchase. It is also different with previous research in terms of the product category. It analyzes Korean cosmetics product that is widely consumed in Indonesia.
In a very high competition, the role country of origin is important since this could urge someone to buy a product. Therefore, the purpose of this research is to describe country of origin and purchase decision from consumer perspective, and to analyze the influence of country of origin on purchase decision. The hypotheses of this research are:

H1: Country Beliefs has a positive influence on Purchase Decision.

H2: People Affect has a positive influence Purchase Decision.

H3: Desire Interaction has a positive influence Purchase Decision.

\section{LITERATURE REVIEW}

\section{A. Country of Origin}

Country of origin is defined as the picture, the reputation, the stereotype that businessmen and consumers attach to products of a specific country [9]. It is a consumer perception towards a product or brand [8]. Form the above definitions, it can be inferred that $\mathrm{COO}$ is consumer perception toward a product or a brand based its home country that it could influence consumer evaluation on the product itself. $\mathrm{COO}$ represents symbolic and emotional meaning to its consumer about the home country of the product [1]. Consumer frequently relies on $\mathrm{COO}$ as a requirement to assess quality of the product. Consumer holds culture stereotype of countries that will influence their assessment of the product [3]. COO can cause advantages and disadvantages for a brand. For brand coming from home country with good quality image, this could be an advantage. On the other hand, for brand coming from home country with poor quality image, this could be a disadvantage.

Many consumers in developing countries viewed $\mathrm{COO}$ as a determinant of the need of a brand as a symbol and status improvement. In other words, using product, which comes from other countries, could increase consumer's social status in development countries. When consumer only has information on from which country the product is produce, therefore purchase decision will be affected by consumer perceptions toward the country. The sub variables of COO are country beliefs, people affect and desired interaction [6]. 


\section{B. Purchase Decision}

Purchase decision is consumer decision on what brand is going to be bought. In evaluation stage, consumer ranks the brands and has developed intention to buy [4]. Generally, consumer will decide which brand he or she likes most to be bought. There are two factors influenced intention to buy and purchase decision. First, is other people's attitude? If someone important to the consumer suggests buying a low price product, then consumer will tend to buy a product with the lowest price. The second factor is unconditional situational factor. Factors that influence consumer purchase intention are expected income, expected price, and product benefit, however, unconditional situational factors such as economic recession, competitors with lower prices, friend giving bad information about the product, could eventually change his/her intention to buy. Therefore, intention to buy is not always followed buy actual purchase. [5] There are six indicators of purchase decision. First is product choice.

Consumer will choose which product to be bought, based on his or her choice. Consumer will decide to use product or service which has value for him or her. Marketers and company must be able to identify consumer needs. Second is brand choice. Consumer should decide which brand that they use. Every brand has its own characteristics. Marketer and company should know how consumer decides which brand that he or she uses. Third is dealer choice. Consumer has to decide which dealer that he or she chooses. Every consumer has different views in making decision on dealer. There are factors such as location, low price, product availability, shopping convenience and place. Fourth is purchase amount. Consumer can decide how many products he or she will buy. Purchasing might be done more than once; therefore marketer and company need to keep their product available at any time for consumer. Next is purchase timing, which is related to when consumer, decide to buy or consume product. The buying pattern is different between one with the other. Some purchase every once a week, once a month, twice a week, twice a month etc. The last one is payment method. This considers with consumer decision toward the type of payment that he or she use to buy product, whether he or she will pay cash, use debit or credit card.

\section{METHODS}

Object of this research is Country of Origin as an independent variable which consists of three sub variables: country beliefs, people affect and desired interaction; and Purchase Decision as dependent variable which consists of six indicators: product choice, brand choice, dealer choice purchase amount, purchase timing, and payment method. The type of this research is survey explanatory method. Data collected through interview, observation, questionnaires and library research. There were 261 Indonesian respondents who use Korean cosmetic product as our sample, using purposive sampling technique. Multiple regression analysis is used to verify the hypotheses.

\section{RESULT AND DISCUSSION}

A. Result

This research included respondents' characteristics and experiences as a general information to know more about the demographic side of consumer. This is shown by the table I.

TABLE I. RESPONDENTS'CHARACTERISTICS AND EXPERIENCES

\begin{tabular}{|c|c|c|c|}
\hline Item & $\%$ & Item & $\%$ \\
\hline Age & & $\begin{array}{l}\text { Purchase } \\
\text { Amount }\end{array}$ & \\
\hline$\leq 20$ yo & $18 \%$ & Once & $27 \%$ \\
\hline $20-30$ yo & $82 \%$ & Twice & $17 \%$ \\
\hline Education & & $\begin{array}{l}\text { More than } \\
\text { Twice }\end{array}$ & $56 \%$ \\
\hline High School & $54 \%$ & Product Item & \\
\hline Diplome & $7 \%$ & Skin care & $21 \%$ \\
\hline Undergraduate & $34 \%$ & Make up & $76 \%$ \\
\hline Graduate & $5 \%$ & Fragrance & $2 \%$ \\
\hline Profession & & Others & $1 \%$ \\
\hline Student & $60 \%$ & Reason to Buy & \\
\hline Fresh Graduate & $2 \%$ & $\begin{array}{c}\text { Reasonable } \\
\text { price }\end{array}$ & $10 \%$ \\
\hline Civil Servant & $6 \%$ & Quality & $26 \%$ \\
\hline Entrepreneurship & $5 \%$ & K Pop Fans & $34 \%$ \\
\hline Employee & $27 \%$ & $\begin{array}{l}\text { Popularity of } \\
\text { the brand }\end{array}$ & $30 \%$ \\
\hline Income & & Brand Bought & \\
\hline$<\mathrm{Rp} 1.000 .000$ & $20 \%$ & Etude & $53 \%$ \\
\hline $\begin{array}{c}\mathrm{Rp} 1.000 .000-\mathrm{Rp} \\
5.000 .000\end{array}$ & $57 \%$ & The Face Shop & $22 \%$ \\
\hline \multirow[t]{4}{*}{$>\operatorname{Rp} 5.000 .000$} & $23 \%$ & It's Skin & $16 \%$ \\
\hline & & Tony Moly & $4 \%$ \\
\hline & & Skin Food & $2 \%$ \\
\hline & & Laneige & $3 \%$ \\
\hline
\end{tabular}

From the data above, we can see that the majority of consumer who buy Korean cosmetic product is 20-30 years old. Most of them are high school graduates who are currently studying in university. Their income mostly lies between Rp. 1.000.000 - Rp. 5.000.000. From their experiences, most of them already bought Korean cosmetic products, mainly make up, more than twice. Major reason to buy Korean cosmetics product because they are K-Pop fans as well as the popularity of the brand itself. They often buy Etude brand, among all of other Korean cosmetics brands.

One of the objectives of this research is to describe country of origin from consumer's perception. In this case, there are three sub variables included; those are country beliefs, people affect, and desired interaction. The data is shown in table II.

From the data shown, it can be concluded that desired interaction has the highest score among other sub variables. This is related with country's image as an innovative country, high level of education and technology, and well known in product design and as a reputable country. People affect consists of employee's level in quality and creativity. Desired interaction involves with the country which is ideal to visit. To know about consumer perception on purchase 
decision, 6 indicators were included. The result is shown in table III.

TABLE II. SCORE OF COUNTRY OF ORIGIN VARIABLE

\begin{tabular}{|c|c|c|c|c|}
\hline No & Sub Variables & Items & $\begin{array}{c}\text { Total } \\
\text { Score }\end{array}$ & $\begin{array}{c}\text { Average } \\
\text { Score }\end{array}$ \\
\hline 1 & Country Beliefs & 4 & 3879 & 970 \\
\hline 2 & People Affect & 2 & 1871 & 936 \\
\hline 3 & Desired Interaction & 1 & 981 & 981 \\
\hline \multicolumn{2}{|c|}{ Total } & 7 & 6731 & 2887 \\
\hline
\end{tabular}

TABLE III. SCORE OF PURCHASE DECISION

\begin{tabular}{|c|c|c|c|c|}
\hline No & Indicators & Items & $\begin{array}{l}\text { Total } \\
\text { Score }\end{array}$ & $\begin{array}{l}\text { AVR. } \\
\text { Scor e }\end{array}$ \\
\hline 1 & Product Choice & 2 & 1955 & 978 \\
\hline 2 & Brand Choice & 2 & 1916 & 958 \\
\hline 3 & Dealer Choice & 3 & 2681 & 894 \\
\hline 4 & Purchase Amount & 2 & 1555 & 778 \\
\hline 5 & Purchase Timing & 2 & 1701 & 851 \\
\hline 6 & Payment Method & 2 & 1576 & 788 \\
\hline
\end{tabular}

From table III above, it can be inferred that indicator that has the highest score is product choice. This not related with the function of cosmetics product to care an maintain our face and moreover to do the make-up.

TABLE IV. CORRELATIONS OUTPUT

\begin{tabular}{|c|c|c|c|c|c|}
\hline & & $\begin{array}{c}\text { Purch ase_ } \\
\text { Decision }\end{array}$ & $\begin{array}{c}\text { Country_ } \\
\text { Beliefs }\end{array}$ & $\begin{array}{c}\text { People_Af } \\
\text { fect }\end{array}$ & $\begin{array}{l}\text { Desired_i } \\
\text { nteraction }\end{array}$ \\
\hline \multirow[t]{4}{*}{$\begin{array}{c}\text { Pearson } \\
\text { Correlation }\end{array}$} & $\begin{array}{c}\text { Purchase_D } \\
\text { ecision }\end{array}$ & 1.000 & .721 & .662 & .611 \\
\hline & $\begin{array}{c}\text { Country_Be } \\
\text { liefs }\end{array}$ & .721 & 1.000 & .804 & .757 \\
\hline & $\begin{array}{c}\text { People_Affe } \\
\text { ct }\end{array}$ & .662 & .804 & 1.000 & .693 \\
\hline & $\begin{array}{c}\text { Desired_int } \\
\text { eraction }\end{array}$ & .611 & .757 & .693 & 1.000 \\
\hline \multirow[t]{4}{*}{ Sig. (1-tailed) } & $\begin{array}{c}\text { Purchase_D } \\
\text { ecision }\end{array}$ & . & .000 & .000 & .000 \\
\hline & $\underset{\text { liefs }}{\text { Country_Be }}$ & .000 & . & .000 & .000 \\
\hline & $\underset{\text { ct }}{\text { People_Affe }}$ & .000 & .000 & . & .000 \\
\hline & $\begin{array}{c}\text { Desired_int } \\
\text { eraction }\end{array}$ & .000 & .000 & .000 & . \\
\hline \multirow[t]{4}{*}{$\mathrm{N}$} & $\begin{array}{c}\text { Purchase_D } \\
\text { ecision }\end{array}$ & 261 & 261 & 261 & 261 \\
\hline & $\underset{\text { liefs }}{\text { Country_Be }}$ & 261 & 261 & 261 & 261 \\
\hline & $\underset{\text { ct }}{\text { People_Affe }}$ & 261 & 261 & 261 & 261 \\
\hline & $\begin{array}{c}\text { Desired_int } \\
\text { eraction }\end{array}$ & 261 & ${ }^{261_{c}} \mathrm{So}$ & 261 26 & result, 2015 \\
\hline
\end{tabular}

Normality testing on regression model is data testing to analyze and to know whether or not dependent or independent variable data distributes normally. Data has a normal distribution if the spread follows the diagonal line from low left to up right. Using SPSS 22.0 for windows, it shows that data are scattered along the diagonal line. This means that this data distributes normally.
Correlation analysis is used to analyze the relationship of variables whether $t$ has correlation between independent and dependent variables and how strong is the correlation. In this research, product moment correlations analysis is used with the help of software SPSS 22.0 for Windows. Before the analysis, ordinal data is transformed into interval data using Method of Successive Interval (MSI). Table IV show the result of correlations analysis.

Based on data above, coefficient correlation of country beliefs with purchase decision is 0,721 , coefficient correlations of people affect with purchase decision is 0,662 , and coefficient correlations of desired interaction with purchase decision is 0,611 . These three coefficient correlations lie between coefficient intervals of $0,600-$ 0,799 . This shows that there is a high correlation between variables. Positive coefficient correlation means that the better country beliefs perceived by consumer, the more consumer will buy a product. This means, it is predicted that purchase decision will increase as the country beliefs going better. The table below summarized the multiple correlations output between country beliefs (X1), people affect (X2), desired interaction (X3) and purchase decision (Y), using multiple correlations analysis.

TABLE V. MULTIPLE CORRELATIONS OUTPUT

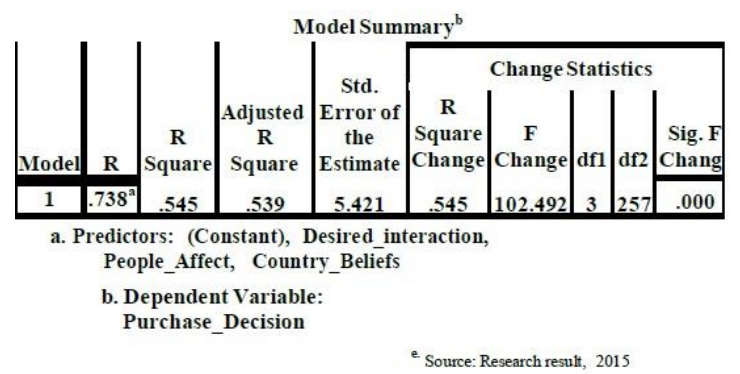

Based on table above, coefficient correlations between country beliefs, people affect, and desired interaction on purchase decision is 0,738 , simultaneously. $\mathrm{R}$ Square or coefficient of determination is 0,545 , meaning that purchase decision is influenced by country beliefs, people affect, and desired interaction by $54,5 \%$. The rest, that is $45,5 \%$ is influenced by other factors which are not covered in this research. F test in this research used ANOVA output table, as follow.

TABLE VI. FTESTING SIGNIFICANCY

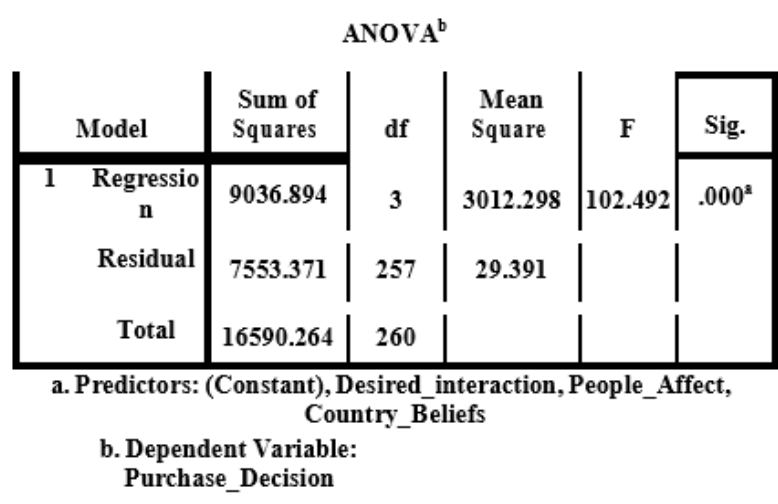


From the above table, it is inferred that F count is 102 , 492 while $\mathrm{F}$ table with degree of freedom $\mathrm{df}=\mathrm{n}-\mathrm{k}-1=$ 259 is 2,62. From the hypotheses testing, it is known that Fcount $>$ Ftable, that is $102,492>2,62$. This shows that H0 is rejected and therefore $\mathrm{H} 1$ is accepted. This means that there is a positive influence of country beliefs, people affect, and desired interaction on purchase decision. T test is done by using coefficient output table, SPSS 22.0 for windows. The result is as follow in table VII.

\section{TABLE VII. TTEST SIGNIFICANCE}

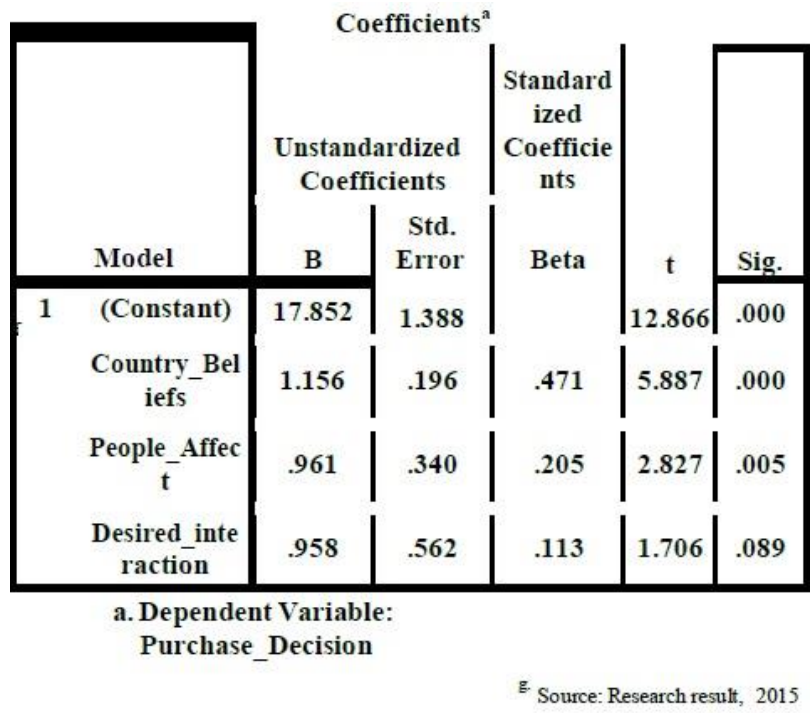

Furthermore, T Test is used to know the influence of country beliefs (X1), people affect (X2), desired interaction (X3) on purchase decision (Y), partially. T Test shows score of 5,887 for country beliefs, 2, 827 for people effect, and 1,706 for desired interaction. Using $=0,05$ and degree of freedom $\mathrm{n}=2=259, \mathrm{t}$ table score is 1,654 . By comparing t table with $t$ table, result shows that $\mathrm{t}$ count for country beliefs of 5,887 is greater than $\mathrm{t}$ table. Therefore, $\mathrm{H} 0$ is rejected and $\mathrm{H} 1$ is accepted. This means that there is a positive influence of country beliefs on purchase decision. The $t$ count for people affect is 2,827 . This is also greater than the score of $t$ table. It means that $\mathrm{H} 0$ is rejected and $\mathrm{H} 1$ is accepted. So it can be inferred that there is a positive influence of people effect on purchase decision. The same thing happens with desired interaction which has $t$ table of 1,706 . Although it is the smallest score compare with the others, but still it is greater than the score of $\mathrm{t}$ table. This also means that $\mathrm{H} 0$ is rejected and $\mathrm{H} 1$ is accepted, and thus, desired interaction has a positive influence on purchase decision.

\section{B. Discussion}

Based on score of country of origin variable, the highest average score is on desired interaction sub variable. This means consumer perceived South Korean as an ideal country to visit. The lowest sub variable on country of origin variable is people affect. This is related with the quality and creativity of the employees who produced Korean cosmetics. This shows that most of the consumers don't care about the employees who made the product. For them, the country itself gives a very high attractiveness compare with the employee itself. For purchase decision variable, indicator that has the highest score is product choice. Most of the respondent buys the product because of its function that is to maintain and take good care of their skin and face, as well as to do the makeup. Follow by the high demand of the consumer to Korean Pop. Because they love Korean Pop and Korean Drama, they try to imitate what is used or wore by the actress, including make-up. The lowest score goes to purchase amount. Since the price of Korean Cosmetics product is not cheap, most consumers only buy a few items. Mainly, they bought product more than three times but in a few amount each time they buy.

From this research, it can be concluded that country of origin, which consists of country beliefs, people affect and desired interaction, influence purchase decision of Korean cosmetics product, simultaneously and partially. This shows that most of respondent buy cosmetic product based on the popularity of the country. [3] It is also mentioned that country of origin influenced consumer decision in choosing and buying a product. [5] It is stated that country of origin perception influence consumer decision. [7] Consumers use cognitive factors, such as product knowledge, as a result of a rational behavior.

Managing country perception gives benefit for the company's marketing strategy. Therefore, it is concluded that South Korea has already managed their country image very well so that it become attractiveness for the consumer to buy their product.

\section{CONCLUSION}

Country of origin, which consists of country beliefs, people affect, and desired interaction, has been perceived well by consumer of Korean cosmetics product. Purchase decision is categorized in a good rank, based on the perception of consumer of Korean cosmetics product. This research also examines the influence of country of origin on purchase decision. For further study, it is important to explore more on another product categories rather than cosmetics. Factors influencing purchase decision is also important to be studied, such as, promotional tools, pricing strategy or product quality.

\section{REFERENCES}

[1] Fetscherin, Marc \& Toncar, Mark. 2010. "The Effect of The Country of Brand and The Country of Manufacturing of Automobiles: An Experimental Study of Consumers' Brand Personality Perception.

[2] Kaynak, Erdener \& Kara, Ali. 2002. "Consumer Perceptions of Foreign Products: An Analysis of Product Country Images and Ethnocenrism". Europan Journal of Marketing. Vo.36. Iss. 7/8, pp. 928-949

[3] Kotabe, Masaaki \& Helsen, Kristiaan. 2010. "Global Marketing Management" (5th Edition). United States: Wiley

[4] Kotler, Philip \& Armstrong, Gary. 2014. "Principles of Marketing" (14th Edition). Pearson, New Jersey

[5] Kotler, Philip \& Keller, Kevin Lane. 2013. "Marketing Management" (14th Edition). England: Pearson Education 
[6] Listiana, Erna. 2012. "Pengaruh Country Of Origin terhadap Perceived Quality Dengan Moderasi Etnosentris Konsumen". Jurnal Administrasi Bisnis (2012), Vol.8, No.1: hal. 21-47,

[7] Moon, B, J and S. C. Jain. 2002" Consumer Processing of Foreign Advertisements. Roles of Country of Origin Perceptions, Consumer Ethnocentrims, and Country Attitude". International Business Review.Vo.11. pp. 117-138

[8] Wang, Xuehua \& Yang, Zhilin.2011. "Standardization or Adaptation in International Advertising Strategies: The Roles of Brand Personality and Country-Of-Origin Image". Asian Journal of Business Research. Vol. 1. No.2

[9] Francis Piron. 2000. "Consumers' perceptions of the country- oforigin effect on purchasing intentions of (in)conspicuous products", Journal of Consumer Marketing, Vol. 17 Iss 4 pp. 308 321 